\title{
Cold stress at seedlings stage of buckwheat optimizes development of both roots and aboveground biomass and limits the excessive vegetative growth interfering with seed formation (an analytical review)
}

\author{
Nikolay N. FESENKO ${ }^{1}$, Zorrida I. GLAZOVA ${ }^{1}$, Ivan N. FESENKO ${ }^{1,2}$
}

Received May 05, 2020; accepted May 26, 2020.

Delo je prispelo 05. maja 2020, sprejeto 26. maja 2020.

Cold stress at seedlings stage of buckwheat optimizes development of both roots and aboveground biomass and limits the excessive vegetative growth interfering with seed formation (an analytical review)

Abstract: Buckwheat, sown in warmed soil, quickly sprouts, grows and successfully competes with annual weeds. However, such agronomic practice does not always lead to a good grain yield, because a powerful, abundantly flowering buckwheat plants often give only a minimal amount of seeds due to a lack of moisture in the upper layer of soil during flowering. This behavior of buckwheat is described as "overgrowth (with poor seed formation)". This phenomenon is caused by the relative weakness of the root system of this species: the specific feature of buckwheat is a very fast transition to formation of secondary roots, which gives advantages at the first stages of development, but restricts the roots growth later. Buckwheat flowering is stretched in time. First half of this developmental stage which is most important for the grain yield is coincided with the most intensive vegetative growth. The lowered temperature at the seedlings stages slows the growth of the aboveground biomass and accelerates the growth of the roots that at later stages favorably affects the conditions for seeds development and, respectively, the grain yield. It explains why early sowing time is favorable for the grain yield of buckwheat.

Key words: buckwheat; overgrowth; sowing date; grain yield
Hladni stres na razvojni stopnji sejanke navadne ajde optimizira razvoj korenin in nadzemne biomase in omejuje prekomerno vegetativno rast, ki zavira tvorbo semen (analitični pregled)

Izvleček: Navadna ajda, posejana v topla tla hitro vzkali in hitro raste in uspešno tekmuje $\mathrm{z}$ enoletnimi pleveli.Vendar pa takšna agronomska praksa ne vodi vedno k dobremu pridelku zrnja, ker daje močno in obilno cvetenje ajde pogosto le minimalno količino semen zaradi pomanjkanja vode $\mathrm{v}$ zgornjih plasteh tal v času cvetenja. To obnašanje ajde je opisano kot "pretirana rast (s šibko tvorbo semen).Ta pojav povzroča relativna šibkost koreninskega sistema te vrste, katerega posebnost je zelo hiter prehod k tvorbi sekundarnih korenin, kar daje prednost $\mathrm{v}$ začetnem razvoju, a omejuje rast korenin kasneje. Cvetenje navadne ajde je časovno raztegnjeno. Prva polovica tega razvojnega obdobja, ki je najpomembnejša za pridelek zrnja soupada $\mathrm{z}$ najmočnejšo vegetativno rastjo. Znižanje temperature na razvojni stopnji sejanke upočasni rast nadzemnega dela in pospeši rast korenin, kar v kasnejših fazah razvoja ugodno vpliva na razmere za razvoj semen in s tem na pridelek zrnja. To razloži zakaj je zgodnja setev navadne ajde ugodna za pridelek zrnja.

Klučne besede: navadna ajda; pretirana rast; čas setve; pridelek zrnja

1 Federal Scientific Center of Grain Legumes and Groats Crops, 302502, p/o Streletskoe, Orel, Russia

2 Corresponding author, e-mail: ivanfesenko@rambler.ru 


\section{INTRODUCTION}

Common buckwheat, Fagopyrum esculentum Moench., is a nectariferous plant with prolonged flowering (usually up to harvesting), which is cultivated in many countries of the northern hemisphere as a grain crop, appreciated for the excellent dietary and healing properties of products from its grain. Maintenance of obligate crosspollination in plants is usually associated with significant energy costs (Solbrig, 1979; Cruden \& Lyon, 1985). In buckwheat, the attraction of pollinators (mainly bees) is provided by excessively abundant, showing flowering. More than $90 \%$ of the flowers do not form seeds and die off (buckwheat flower lives 1 day). Such or close to this manner of flowering and seed formation is quite typical for buckwheat and can be considered the norm. Sometimes seed formation could be increased, and some optimists found it possible to talk about a very high potential for buckwheat grain productivity $\left(>10 \mathrm{t} \mathrm{ha}^{-1}\right.$, if most of the flowers give seeds). However, in buckwheat, the period of the beginning of flowering is overlapped with the most intensive vegetative growth, and under unfavorable conditions (for example, drought), the vegetative growth has an advantage over seed formation, which leads to the mass death of emerging ovaries (Fesenko, 1983). At the same time, the advantage of vegetative growth can present itself even more clearly in very favorable conditions of abundance of moisture and mineral nitrogen in the soil, when the powerful coenosis with abundant flowering doesn't exhibit the appropriate formation of seeds. Such behavior of buckwheat in Russian agronomic jargon is described by the term "zhirovanie" (the approximate translation is "obesity", but the common sense is the "overgrowth with poor seed formation" or, shorter, the "overgrowth"). This is the most distinct for powerful, i.e. later-ripening buckwheat varieties. In this context, buckwheat had a reputation of a "mysterious" crop that could give an acceptable yield on poor soil and, on the contrary, on rich soil the yield could be poor despite the powerful growth and abundant flowering.

There are fairly reliable guesses about the nature of this phenomenon (Fesenko, 1983), however, it was not possible to do special experiments revealing the physiological mechanism of "the overgrowth", and this article became possible only as a summary of various sources, the reason for collecting which was the impressions of first author when visiting the agrotechnical experiment studying the sowing time of the variety Ballada in 1983. This variety, quite late ripening and powerful, turned out to be a "model" for studying the "overgrowth", and the year 1983 was a provocative for a clear manifestation of this phenomenon (unusually early, warm and humid spring and hot, moderately moistened summer). This ex- periment was conducted during several years (Shashkin \& Mazalov, 1992), but only in 1983 the "overgrowth" proved to be a full-fledged qualitative trait, whereas in other years of this work, as well as in other cited works with accents to sowing dates, this phenomenon could be recognized only by quantitative differences in grain yield.

Trying to identify the physiological mechanism so strongly affecting the buckwheat grain yield we found it necessary to do this in context of the specific climatic conditions of the northern farming systems which influenced the results of cited works.

The "line" limiting agriculture from the North crosses the entire territory of Russia and can be prolonged through Japan (Hokkaido) and Canada where buckwheat is also cultivated. The border status is associated with the concept of "risk farming zone". The main limiting factor here is a short frost-free period, which often complicates the formation of soil with good characteristics. This can restrict the yield of main grain crops. Under such conditions, buckwheat can be quite competitive as a relatively unpretentious crop.

Frost-resistant spring cereals are sown as soon as possible, sometimes almost immediately after snowmelt, to avoid mass diseases and insects damages. Frost-sensitive buckwheat is the later crop, which is sown a month later, when nightly frosts possibility becomes minimal.

It allows carry out the effective eliminating weeds' seedlings by mechanical soil cultivation before sowing. Buckwheat seeds sown in a well-warmed soil prepared in this way quickly germinate, and the young plants are able to quickly cover the threadlike seedlings of annual weeds. These are the criteria for an optimal sowing period. But how does this affect the grain harvest? This is the topic of our review, where we collected the observations of buckwheat made since the start of breeding work with it in the Orel region and other regions of the world, which together provide an opportunity to explain the features of its yield' reactions to growing conditions. In the article is also mentioned Tartary buckwheat, F. tataricum Gaertn, a self-pollinated species, which at present time has a prospect to be introduced into Russian agriculture.

\section{OREL REGION (RUSSIA), $53^{\circ} \mathrm{N}$}

This region is considered favorable for the cultivation of main crops, including buckwheat. Here we can use the written and personal testimonies of researchers over the past century, during which revolutionary changes occurred in the energy saturation of agriculture and, accordingly, in standard agricultural technology.

In the period before the widespread of agricultural machinery, plowing of the fields was carried out mainly 
by horse-drawn wooden plough, that is, without furrow slice inversion. This led: 1) to delay spring plowing and sowing of early spring crops, which is why large areas were sown with late spring crops (buckwheat, millet); 2) to accumulation of weeds' rhizomes. In the fields with the most weediness after snow melting spring grazing of cattle was carried out, and plowing and sowing of buckwheat were conducted in June (Krotov, 1960).

Local buckwheat was of an early maturing type, but, apparently, these populations were quite heterogeneous in a number of properties, and on their basis as result of long-term (from 1901 to 1909) earlier (May) sowing and machine sorting of seeds a more powerful and largegrained mid-ripening variety Bogatyr was developed at the Shatilov's Research Station (Fesenko, 1990).

After widespread of machine agriculture, autumn plowing, as well as early spring plowing became the norm, that allowed for timely spring sowing on unlimited areas. It sharply reduced the pest damage to early spring seedlings, and barley, having the opportunity to "get away" from the mass defeat by the Oscinella sp., became the most technologically advanced and productive spring crop. As a result, late spring crops began to decline fast. But the "atomic era" has reversed this process, as in Russia buckwheat has become mandatory when planning sowing areas.

The machines era fixed the optimal timing of sowing buckwheat in Orel region for the third decade of May for more than half a century. It was confirmed in agrotechnical experiments (Losev \& Khlebnikov, 1973). Earlier sowing was considered impractical due to the higher probability of night frosts and the lack of time for presowing weed control (Losev \& Khlebnikov, 1973).

The weather dynamics in the spring months follow a standard scenario, but significant variation is possible between years. At the beginning of the 1980s, earlier and warmer springs became frequent in the Orel region, which is probably consistent with the syndrome of global warming. In those years, the system of regional experimental agricultural institutions has actively working in the USSR. New types' varieties of buckwheat were created in Institute of Grain Legumes and Groats Crops. It required studying varietal agricultural technology, including experiments with sowing dates. In 1983-1991 such experiments were carried out with new mid-ripening buckwheat variety Ballada (Shashkin \& Mazalov, 1992) which was sown in the following dates: 1) May 8-11;2) May 15-16; 3) May 24-26 (standard); 4) June 5-6 and 5) June 9-11. In terms of grain yield depending on the sowing dates next results were obtained (average and range): 1) $1.89(1.49 \ldots 2.60) \mathrm{t} \mathrm{ha}^{-1}$; 2) $1.68(1.07 \ldots 2.34) \mathrm{t} \mathrm{ha}^{-1}$; 3$)$ $1.51(0.37 \ldots 2.02) \mathrm{t} \mathrm{ha}^{-1}$; 4) $0.88(0.09 \ldots 1.96) \mathrm{t} \mathrm{ha}^{-1}$; 5$)$ $0.54(0.06 \ldots 1.22) \mathrm{t} \mathrm{ha}^{-1}$.
Thus, the maximum yield was obtained at the first (early) term of sowing, the following periods were characterized first by a smooth (terms 2 and 3), and then by a sharp (terms 4 and 5) decline in grain yield with the excellent appearance of these plots. The authors explained the result by the fact that the first sowing period allowed the Ballada cultivar 6 years out of 9 catches the most favorable conditions in the first half of the flowering period which was critical for buckwheat (Shashkin \& Mazalov, 1992). In parallel experiment with a new early ripening variety Skorospelaya 86, the largest grain yield was obtained after sowing on May 14-16 and May 24-26, which was explained from the same standpoint (Shashkin \& Mazalov, 1992).

\section{HOKKAIDO (JAPAN), 43-44 ${ }^{\circ} \mathrm{N}$}

The island is located far south of Orel, however, the surrounding sea is cold and agricultural development of the island has occurred recently, i.e. to the beginning of the $20^{\text {th }}$ century. The optimal time for sowing buckwheat here is considered the beginning of June. Later sowing is also practiced (Honda et al., 2010).

The paper by Honda et al.(2010) presents data for 5 years $(2004 \ldots 2008)$ obtained for three varieties that were sown in three terms: mid-May (early), early June (standard) and the end of June (late). The varieties under the study were different in morphological type: 'Kitawasesoba' is the large-grained standard, 'Kitayuki' is the late-ripening small-grained variety, and 'Kitanomashu' is the new determinant variety.

The varieties showed quite noticeable differences in grain productivity (Kitanomashu $>$ Kitawasesoba $>\mathrm{Ki}$ tayuki), but a very similar reaction both to the sowing date and to the conditions of the year. All three varieties gave the maximal average (for five years) grain yield after early sowing: three years out of the five all the varieties manifested better results at early sowing compared to sowing in "optimal period". The authors concluded that the advantage of early sowing was due to the best weather conditions during the flowering period, which 3 years out of five was provided by early sowing. The authors also cited the Canadian (Gubbels, 1977) and Japanese works in which similar results were obtained.

\section{DISCUSSION}

There is a relationship between genetically determined traits of root and crop productivity (Kell, 2011; Narayanan et al., 2014). Since the root system is a dynamic formation that is influenced by environmental fac- 
tors (Lynch, 1995; Grossman \& Rice, 2012), the success of breeding changes in the root system in crops depends not only on a specific trait and the nature of its inheritance, but also on the use of a particular farming system together with soil characteristics (Botwright Acuna \& Wade, 2012; Meister et al., 2014).

Buckwheat belongs to the group of plants in which the initiation and development of primordia of the lateral roots occurs in the apical meristem of the main root (O’Dell \& Foard, 1969). In addition, due to the initiation of the groups of primordia of lateral roots in embryogenesis, these species are characterized by early branching of the main root after germination (Dubrovsky \& Laskowski, 2017). The rapid development of the root system allows compete with representatives of other species for soil resources and quickly gain significant biomass (Ilyina et al., 2017).

At the same time, buckwheat is much inferior to the grain cereals in the final development of the root system (Hagiwara et al., 1998), surpassing them in absorption capacity of roots (Fesenko, 1983). Therefore, the relative weakness of the buckwheat root system may be the cause of the instability of its grain productivity. The effect of the overgrowth with poor seed formation is especially explicit, when buckwheat, after sowing under favorable conditions, develops a powerful above-ground vegetative mass, actively blossoms, but gives a low grain yield.

From this point of view, the experiments by Park et al. (2010), who were optimizing the process of buckwheat seeds germination to obtain seedlings for early spring salad, are interesting. Seeds $(30 \mathrm{~g})$ were washed and soaked at a temperature of $25^{\circ} \mathrm{C}$. The seeds that started to germinate were divided into 3 fractions of $10 \mathrm{~g}$ each and placed on the steel tray with double layer steel net. The seedlings were grown in the dark under optimal moisture conditions and at stable temperature of $20^{\circ} \mathrm{C}$, $25^{\circ} \mathrm{C}$, and $30^{\circ} \mathrm{C}$, respectively. On the $9^{\text {th }}$ day of such cultivation, the seedling yield was weighed and the length of their roots was measured.

In common buckwheat F. esculentum, the seedling yield was the smallest at $20{ }^{\circ} \mathrm{C}(1.66 \mathrm{~g})$ and increased sharply with increasing temperature to $25^{\circ} \mathrm{C}(2.73 \mathrm{~g})$ and, especially, to $30^{\circ} \mathrm{C}(3.30 \mathrm{~g})$. At the same time, the root length was maximal at $20^{\circ} \mathrm{C}(5.93 \mathrm{~cm})$, with increasing temperature it decreased to $4.80 \mathrm{~cm}$ at $25^{\circ} \mathrm{C}$ and to $5.23 \mathrm{~cm}$ at $30^{\circ} \mathrm{C}$.

This experiment did not aim to determine the root availability of the obtained plants depending on the temperature of cultivation, however, we can use its results for a comparative description of the share of roots in the obtained plant biomass, because the mass of seeds in the studied variants was the same $(10 \mathrm{~g})$, but the mass of seedlings varied sharply. The ratio of root length to bio- mass was $5.93 \mathrm{~cm}: 1.66 \mathrm{~g}=3.57 \mathrm{~cm} \mathrm{~g}^{-1}$ at $20^{\circ} \mathrm{C}, 4.80 \mathrm{~cm}$ : $2.73 \mathrm{~g}=1.76 \mathrm{~cm} \mathrm{~g}^{-1}$ at $25^{\circ} \mathrm{C}$ (i.e. 2 times less than at $20^{\circ} \mathrm{C}$ ) and $5.23 \mathrm{~cm}: 3.30 \mathrm{~g}=1.59 \mathrm{~cm} \mathrm{~g}^{-1}$ at $30^{\circ} \mathrm{C}$ (i.e. 2.2 times less than at $20^{\circ} \mathrm{C}$ ).

Thus, at the earliest stage of plant development under optimal growth conditions, the misbalance was initiated, which after beginning of flowering can sharply negatively affect the formation of the grain yield as the fast growth of the aboveground biomass was not sufficiently supported by a more slowly growing root system.

A similar trend could be observed when F. tataricum seeds were germinating, but taking into account their smaller size (the conditions were the same)(Park et al., 2010). The seedling yield here was $1.06 \mathrm{~g}$ at $20^{\circ} \mathrm{C}, 1.86 \mathrm{~g}$ at $25^{\circ} \mathrm{C}$ and $1.90 \mathrm{~g}$ at $30^{\circ} \mathrm{C}$. In this case, the length of the roots differed slightly: $4.86 \mathrm{~cm}, 4.90 \mathrm{~cm}$ and $5.13 \mathrm{~cm}$, respectively. The biomass yield at $25{ }^{\circ} \mathrm{C}$ increased 1.75 times compared to $20^{\circ} \mathrm{C}$, and the ratio "root : biomass" decreased, respectively, from $4.58 \mathrm{~cm} \mathrm{~g}^{-1}(4.86 \mathrm{~cm}$ : $1.06 \mathrm{~g})$ to $2.63 \mathrm{~cm} \mathrm{~g}^{-1}(4.90 \mathrm{~cm}: 1.86 \mathrm{~g})$. These indicators are higher than those of $F$. esculentum, however, the tendency was clearly manifested: higher temperature leads to an increase in the aboveground biomass with a decrease in its root support.

In our analysis of this experiment, the categories "more/less" were used, i.e. here we begin to consider the overgrowth with poor seed formation as a quantitative trait. This allows us to include in the analysis not only extreme cases, but also almost the entire set of facts obtained during the experimental and practical cultivation of buckwheat. Such an approach makes it possible to distinguish between the level of imbalance between the power of the entire biomass of the plant and its root support, and evaluate this trend for any variety.

Powerful mid-ripening and late-ripening varieties are usually prone to the overgrowth with poor seed formation under favorable conditions including fertilized soil, while rapidly blooming early ripening varieties are genetically more resistant to this phenomenon. So, the early-ripening variety Skorospelaya 86 manifested the best result when sowing date was standard, but the midripening variety Ballada, prone to strong growth, shown best yield when sowing in the earliest terms (Shashkin \& Mazalov, 1992), i.e. when temperature was lower. In addition, the Ballada variety gave the smallest sum of yields in the five sowing terms in 1983, when the most favorable combination of early heat and moisture supply was being. That year, at early sowing date, the yield was only $1.56 \mathrm{t} \mathrm{ha}^{-1}$, in contrast with the perfect characteristics of the cenosis in all other aspects, the second sowing term showed $1.12 \mathrm{t} \mathrm{ha}^{-1}$, and the yield of the next three periods was $0.37,0.09$ and $0.06 \mathrm{tha}^{-1}$ also in spite of perfect characteristics of the fields, i.e. the proportions of their 
vegetative development and grain yield more and more clearly consistent with the concept of excessive vegetative growth with poor seed formation. The maximal yield was experimentally obtained in a rather cool $1990\left(2.6 \mathrm{t} \mathrm{ha}^{-1}\right.$ with early sowing) (Shashkin \& Mazalov, 1992). The variety Ballada is able to form a larger biomass than the Bogatyr and Krasnostreletskaya varieties, which showed the best result when sowing in the third decade of May 18 years before (Losev \& Khlebnikov, 1973).

Japanese varieties are sensitive to light day length (short-day type) and exhibit enhanced branching in Hokkaido (Fesenko et al., 1999), i.e. form a powerful, even excessive biomass. According to the cited publication (Honda et al., 2010), the alteration of this genotype into a determinant type of growth was very effective, because a new determinant variety has proven itself as the most productive. In this work, it was noted that early-sown plants were shorter than those sown in June. The authors concluded that the increase in yield in the first term was associated with increased resistance to lodging (Honda et al., 2010). At the same time, it can be a consequence of both the reaction of the short-day varieties on a shorter day in May, and a heat deficiency at this time. However, a decrease in above-ground biomass can be functionally associated with better root support of the flowering and seed formation processes. It is necessary to note the best root support of the seed filling process is one of the advantages of determinant buckwheat varieties over ones with indeterminate growth habit (Martynenko, 1988).

An earlier sowing period is usually associated with a greater likelihood of night frost. Not all May night frosts observed in the Orel region were fatal for buckwheat. If the frost was due to cold and wet weather, most often a partial freezing of seedlings was observed, which, however, did not always affect the final result, because the surviving plants were sufficient for the formation of a grain yield in conditions of reduced competition. Interestingly, in the Hokkaido experiment, the maximum grain yield was obtained in 2007, when the seedlings of the first sowing period fell under freezing on May 28 (Honda et al., 2010). Apparently, the moist marine climate played the role of a buffer and did not allow the temperature to drop below a critical level, and the inhibition of the aboveground biomass growth appeared to be optimal for harmonizing the process of seed formation.

Frost together with drought is more dangerous when large daily temperature fluctuations are possible, for example, from $+17^{\circ} \mathrm{C}$ during the day to $-3{ }^{\circ} \mathrm{C}$ at the end of the night. The geographical conditions of continental Canada and Siberia suggest a high probability of such severe night frosts in late spring. Canadian varieties are quite late-ripening, and for this reason are prone to form excess biomass when sowing in the frost-free period. This is probably why the Canadian buckwheat breeding program emphasized the development of frostresistant varieties (Campbell, 2003). Similar work was carried out in Siberia (Kostyro, 1971). But it is too early to talk about the successes of this direction.

Theoretically, it is possible to minimize the effect of the "overgrowth" after sowing in heated soil using effective retardants that reduce the vegetative growth of buckwheat plants. Occasionally, publications appear in which a physiologically active substance is considered as a factor that dramatically increases the yield of buckwheat grain. An example is the article by Szelezniak et al. (2010), which describes the experience of herbicides application on buckwheat crops. Only chemicals to which buckwheat is relatively tolerant have been compared. Sowing was carried out on May 26, 2009, i.e. into warm soil. Interestingly, all seven of the studied chemicals gave an increase in grain yield; three of them gave the increase more than 2 times. Since all these herbicides can be regarded as retardants in terms of the physiological effect on buckwheat, it can be assumed that their use not only reduced competition from weeds, but also optimized the root support of the plant generative sphere during flowering due to reduction of aboveground biomass, also reducing auto-competition in the cenosis.

Unfortunately, the cited work, like many others, does not provide significant information on the physiological effects of the chemicals on plant organs. Our approach based on a quantitative analysis of the "overgrowth" in buckwheat can stimulate such studies. It seems that the level of root development (and final yield) of the buckwheat plant is largely determined at the first stages of growth, which are most easily controlled by duplicating field experiments by hydroponic ones (Park et al., 2010). It is necessary to note that our conclusions are based not only on the cited results of accurate singlefactor experiments, but also on many years experience in studying buckwheat from various perspectives (genetics, cultivation technology, breeding), which allows us to form an integral natural-philosophical view on the problem. But while, on the existing assortment of buckwheat, French farmers get the maximum yield in the marine climate of the Brittany province (http://www.fao. org). Unfortunately, we do not have information about the peculiarities of the cultivation technology used there. It can be assumed that the absence of late spring night frosts over the years (the Gulf Stream influence) allows early buckwheat sowing. As result, the seedlings develop under relatively low positive temperatures, which stops the premature excessive vegetative growth of the variety La Harpe widespread there. Therefore, its plants begin to bloom when the root system achieved maximum possible development (relative to the above-ground biomass), 
sufficient to provide flowering and seed formation, which in this developmental phase is overlapped with intensive vegetative growth.

\section{REFERENCES}

Botwright Acuna, T.L., Wade L.J. (2012). Genotype $\times$ environment interaction for root depth of wheat. Field Crops Research, 137, 117-125. https://doi.org/10.1016/j. fcr.2012.08.004

Campbell, C. (2003). Buckwheat crop improvement. Fagopyrum, 20, 1-6.

Dubrovsky, J.G., Laskowski, M. (2017). Lateral root initiation. In:B. Tomas, B.G. Murray \& D.G. Murphy (Eds.) Encyclopedia of applied plant sciences ( $2^{\text {nd }}$ edition)(pp. 256-264). Oxford: Academic Press.

Fesenko, N.N., Martynenko, G.E., Funatsuki, H., Romanova, O.I. (1999). Comparison of some buckwheat cultivars in conditions of Russia and Hokkaido using morphological descriptors-indicators of duration of vegetation period. Research Bulletin of Hokkaido National Experimental Station, №267, 149-156.

Fesenko, N.V. (1983). Breeding and seed farming of buckwheat. Moscow: Kolos. (in Russian)

Fesenko, N.V. (1990). Research and breeding work with buckwheat in USSR (Historic Survey). Fagopyrum, 10, 47-50.

Grossman, J.D., Rice, K.J. (2012). Evolution of root plasticity responses to variation in soil nutrient distribution and concentration. Evolutionary Applications, 5, 850-857. https:// doi.org/10.1111/j.1752-4571.2012.00263.x

Gubbels, G.H. (1977). Interaction of cultivars sowing date and sowing rate on lodging, yield and seed weight of buckwheat. Canadian Journal of Plant Science, 57,317-321. https://doi. org/10.4141/cjps77-048

Hagiwara, M., Inoue N., Matano, T. (1998). Allometry among roots, leaves and flower clusters in common buckwheat. Fagopyrum, 15, 29-34.

Honda, Y., Mukasa, Y., Suzuki, T. (2010). Effect of earlier sowing on summer type of common buckwheat in the northern area of Japan. In: V.I. Zotikov, N.V. Parakhin (Eds.) Proceedings of 11th International Symposium on Buckwheat (pp. 612-615). Orel: Kartush.

Ilina, E.L., Kiryushkin, A.S., Tsyganov, V.E., Pawlowski, K., Demchenko, K.N. (2017). Molecular, genetic and hormonal outlook in root branching (review). Sel'skokhozyaistvennaya biologiya [Agricultural Biology], 52, 856-868. https://doi. org/10.15389/agrobiology.2017.5.856eng (in Russian)

Kell, D.B. (2011). Breeding crop plants with deep roots: their role in sustainable carbon, nutrient and water sequestration. Annals of Botany, 108, 407-418. https://doi.org/10.1093/ aob/mcr175.

Kostyro, V.P. (1971). Creation of cold-resistant varieties of buckwheat. In: Breeding, genetics and biology of buckwheat (pp. 25-28). Orel: VNIIZBK. (in Russian)

Krotov, A.S. (1960). From the history of buckwheat cultivation in the USSR. In: Materials on the history of agriculture and peasantry of the USSR, (pp. 414-456). Moscow: USSR Academy of Science. (in Russian)

Losev, S.I., Khlebnikov, A.I. (1973). About the timing of sowing buckwheat. Bull. NTI VNIIZBK (Orel), №4, 72-78. (in Russian)

Lynch, J. (1995). Root architecture and plant productivity. Plant Physiology, 109, 7-13. https://doi.org/10.1104/pp.109.1.7

Martynenko, G.E. (1988). Morphobiological features and prospects of breeding of the determinant form of buckwheat. In: Prospects for increasing buckwheat yield and grain quality (pp. 21-24). Kishinev. (in Russian)

Meister, R., Rajani, M.S., Ruzicka, D., Schachtman, D.P. (2014). Challenges of modifying root traits in crops for agriculture. Trends in Plant Science, 19, 779-788. https://doi. org/10.1016/j.tplants.2014.08.005

Narayanan, S., Mohan, A., Gill, K.S., Prasad, P.V.V. (2014). Variability of root traits in spring wheat germplasm. PLoS ONE, 9, e100317. https://doi.org/10.1371/journal.pone.0100317.

O'Dell, D.H., Foard, D.E. (1969). Presence of lateral root primordia in the radicle of buckwheat embryos. Bulletin of the Torrey Botanical Club, 96, 1-3. https://doi. org/10.2307/2484002

Park, C.H., Kim, J.H., Chang, K.J., Woo, S.H., Lee, M.H., Briatia, X. (2010). Effect of temperature, deep sea water, and seed quality on growth of buckwheat sprouts. In: V.I. Zotikov, N.V. Parakhin (Eds.) Proceedings of 11th International Symposiumon Buckwheat (pp. 631-636). Orel: Kartush.

Shashkin, Yu.A., Mazalov, V.I. (1992). Sowing dates and yield of buckwheat. In:Improving the breeding and technology of cultivating legumes and groats crops (pp. 222-225). Orel: VNIIZBK. (in Russian)

Szelezniak, E., Podolska, G., Rubicki, L. (2010). Influence of herbicides on weed control in buckwheat and buckwheat yielding. In V.I. Zotikov, N.V. Parakhin (Eds.) Proceedings of 11th International Symposium on Buckwheat (pp. 661665). Orel: Kartush.

FAO. (2014). FAOSTAT database. Retrieved from http://www. fao.org/faostat/en/\#home 